\title{
The Effectivity of Murottal Al-Qur'an Exposure to Spermatogenesis of Male Mice (Mus musculus) with stress
}

\section{Meilina Ratna Dianti ${ }^{1}$, Lilik Khoiriyatul Mazidah $^{2 *}$, Yen Yen Ari Indrawijaya ${ }^{3}$ and Fidia Rizkiah Inayatilah ${ }^{4}$}

1,2,3 Departement of Pharmacy, Faculty of Medicine and Health Science, UIN Maulana Malik Ibrahim, Malang, Indonesia

*Corresponding author

Email: mazidah198@gmail.com

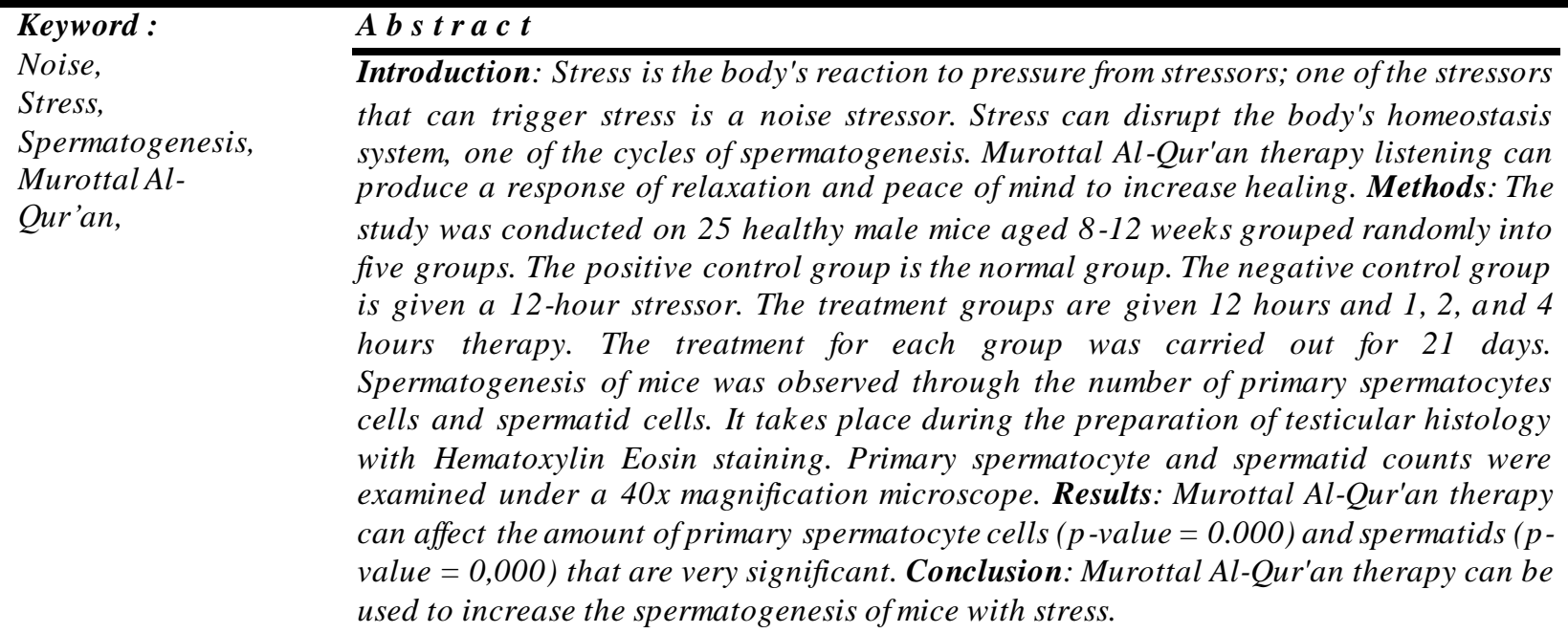

How To Cite : Dianti, M.R., Mazidah,L.K., Indrawijaya, Y.Y.A.,\& Inayatilah, F.R.2021. The Effectivity of Murottal Al-Qur'an Exposure to Spermatogenesis of Male Mice (Mus musculus) with stress.5(2),64-70. https://doi.org/10.18860/jim.v5i2.9886

Copyright $\odot 2021$

\section{INTRODUCTION}

Stress is a negative emotional experience that results in changes that a person uses to respond stress. ${ }^{1}$ Stress will change the body's homeostatic system will affect physical and psychological symptoms. ${ }^{2}$ Based on data from the WHO (World Health Organization) in 2016, where around 35 million people in the world experience stress and based on data from Riset Kesehatan Dasar (Riskesdas) in 2013 showed the number of $6 \%$ of the total population of Indonesia experiencing stress. 3,4

One of the disturbed systems is the reproductive system, stress can inhibit the secretion of reproductive hormones so that it will reduce reproductive function. ${ }^{5}$ Stress can reduce the male reproductive system starting with the release of corticotropinreleasing hormone ( $\mathrm{CRH})$ by the hypothalamus. Anterior pituitary responds with secreting the hormone Adenocorticotropin hormone (ACTH), then will stimulating the adrenal cortex, releasing glucocorticoids into the blood circulation. Glucocorticoid inhibits the secretion of gonadotropin-releasing hormone ( $\mathrm{GnRH})$ and reduces the release of luteinezing hormone (LH) and follicle stimulating hormone (FSH). Furthermore, it ultimately suppresses the production of testosterone by Leydig cells, spermatozoa by Sertolli cells, and spermatogenesis. ${ }^{6}$ Based on Apriliani research (2013), stress can decrease spermatogenesis, indicated by a decrease in primary spermatocytes and spermatid cells 
after giving noise stressor for 21 days. $^{7}$ In Rojas' research (2017) stress can decrease testosteron resulting decrease in spermatogenik cells in testes, especially primary spermatocytes and oval spermatid, and inhibiting spermatogenesis. ${ }^{8}$

Murottal physically contains elements of the human voice, which are outstanding healing instruments. Sounds can reduce stress hormones, activate natural endorphins, increase feelings of relaxation, and divert attention from fear, anxiety, and tension, and improve the body's chemical system. ${ }^{9}$ Murottal that is played to humans can affect both the body, where sounds that contain harmonious and regular tones can produce rhythmic stimulation to the central nervous system so that the body becomes stable. This happens because the brain's performance that controls and coordinates all body activities becomes homeostasis. ${ }^{17}$

One of the letters in the Qur'an, which can be used as Murottal therapy is the Ar-Rahman letter. The repetition of verses in Surah Rahman can distract and function as hypnosis that decreases brain waves. The brain will produce the hormones serotonin and endorphin, then, make a person feel comfortable, calm, and happy. ${ }^{10}$ This researchers intend to examine the Effectivity of Al-Qur'an murottal therapy on the spermatogenesis of male mice (Mus musculus) Stress was observed from the number of primary spermatocytes spermatid cells.

\section{METHOD}

This research is an experimental laboratory study with a true experimental design post-test only control group design. It was conducted in December 2019 February 2020 and used 25 healthy Balb / c male mice aged 8-12 weeks.

The noise stressors in this study are the highway's sound from the website https://gudanglagu.site/link/suasana streetjatingaleh-city-semarang-during-work-hours from the first minute to the 6.37 minutes that were exposed during 12 hours (18.00 06.00) with Polytron sound speaker volume 30 , the use of this sound because it has a high and consistent sound intensity (85 - 95 $\mathrm{dB}$ ), and includes the sound range that causes noise. Murottal Al-Qur'an uses Murottal audio of Al-Qur'an Surat ArRohman verses 1-78, which is read by Shaykh Abdur Rahman Asy-sudais from the website https: //qurancentral.com / audio / abdur-rahman-as-sudais given for 1,2, and 4 hours with Polytron loudspeakers volume 8 . Noise and Murottal stressors are provided at a distance of 2 meters from mice. Measurement of noise and Murottal intensity is with Sound level Meter software, Audio selection is based on the stability of the sound intensity $<60 \mathrm{~dB}$.

Mice were acclimatized seven days before treatment, then grouped randomly into five groups. The positive control group is the normal group. The negative control group was given a 12 hours noise stressor, the treatment groups were given a 12 hours noise stressor, and Murottal 1, 2, and 4 hours. The treatment for each group was carried out for 21 days. The mice were terminated and taken one of the testes to make testicular histology preparations by the HE method by experts the Laboratory of Parasitology, Brawijaya University.

The number of primary spermatocyte and spermatid cells was observed with a 40x magnification Olympus microscope and captured using the Optilab software. The calculation of the number of primary spermatocytes and spermatids was done manually with the Image Raster application. Each mice has selected five seminiferous tubules on the cross-section of the testis. The number of spermatogenic cells in the five tubules is then averaged for each mouse. ${ }^{11}$ The data is then processed using the One Way ANOVA method with a significance level ( $p$-value) of 0.05 and a 95\% confidence level with the IBM SPSS Statistics 24 software. 


\section{RESULT AND DISCUSSION}

\section{Results}

\section{Noise Stressors and Audio Murottal Al-Qur'an}

The measurement of noise intensity using sound level meter software obtained sound intensity $85-95 \mathrm{~dB}$, with a frequency of $279-300 \mathrm{~Hz}$, this value is in the noise range. While Murottal has a sound intensity of 36-53 dB with a frequency of $43-63 \mathrm{~Hz}$, this intensity can reduce stres. ${ }^{12}$

\section{Primary Spermatocytes}

Figure 1 shows the number of primary spermatocyte cells in the negative control group, given the noise stressor had the lowest number when compared to other groups. Whereas treatment group 3, which was given noise stressors and 4-hour Murottal Al-Qur'an therapy, showed the highest number of cells compared to other groups.

The results of the analysis used the One Way ANOVA test to determine the differences between treatment groups. It obtained $\mathrm{p}$-value of the five groups is 0.000 , and the value $<0.05$ so that there are significant differences between treatment groups. The murottal Al-Qur'an therapy can influence the spermatogenesis of mice with stress, which seen from primary spermatocyte cell counts between significantly different groups.

\section{Spermatid}

Figure 2 shows the number of spermatid cells in the negative control group, given that the noise stressor had the lowest number compared to other groups. Whereas treatment group 3, which was given noise stressors and 4-hour Murottal Al-Qur'an therapy, showed the highest number of cells compared to other groups.

One Way ANOVA test to determine the differences between treatment groups obtained $\mathrm{p}$-value of the five groups was 0.000 , which the $\mathrm{p}$-value $<0.05$. There is a significant difference between treatment groups; this shows that the murottal AlQur'an therapy can influence the spermatogenesis of stressed mice seen from spermatid cell counts between significantly different groups.

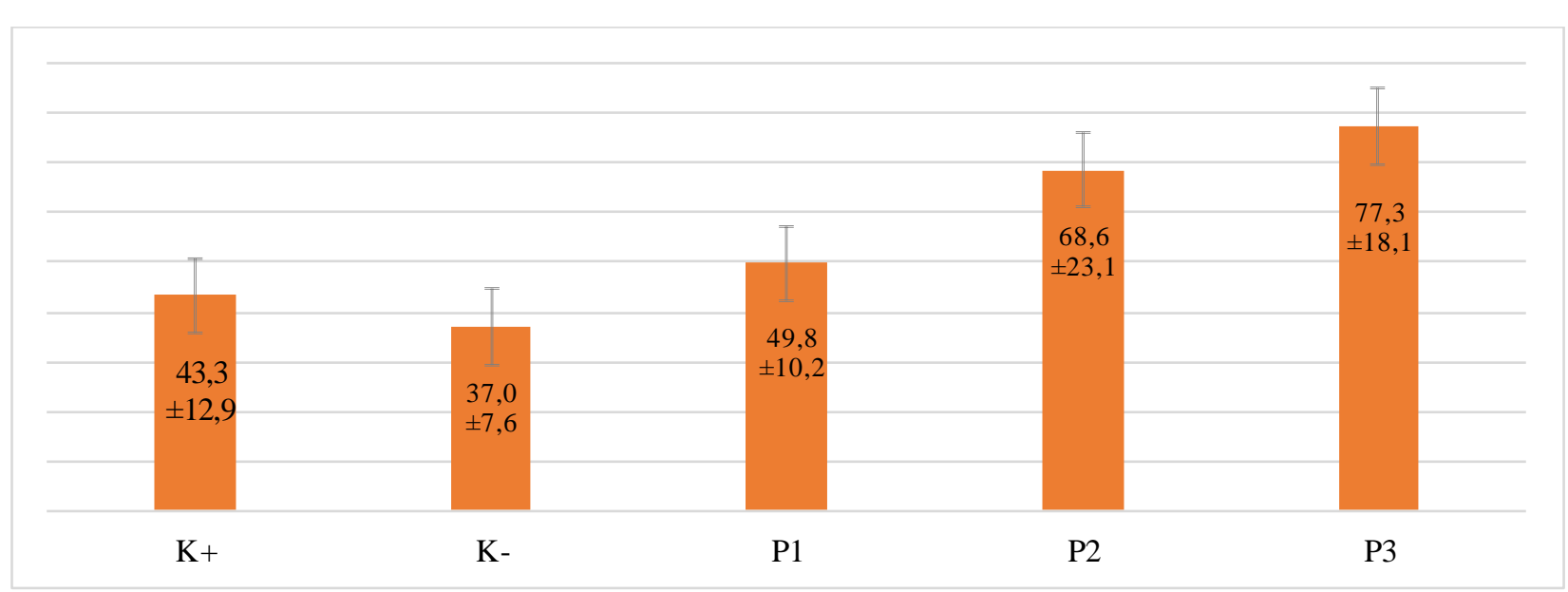

Figure 1 Number of Primary Spermatocyte Cells

*Note: $(\mathrm{K}+)$ Normal Group. $(\mathrm{K}-)$ mice were given a 12-hours noise stressor treatment. $(\mathrm{P} 1)$ mice were treated with 12 hours noise stressors and 1-hour Murottal Al-Qur'an therapy. (P2) mice were given a 12-hours noise stressor treatment and 2-hours Murottal Al-Qur'an therapy. (P3) mice were given a 12-hour noise stressor treatment and 4-hour hours Murottal Al-Qur'an therapy. 


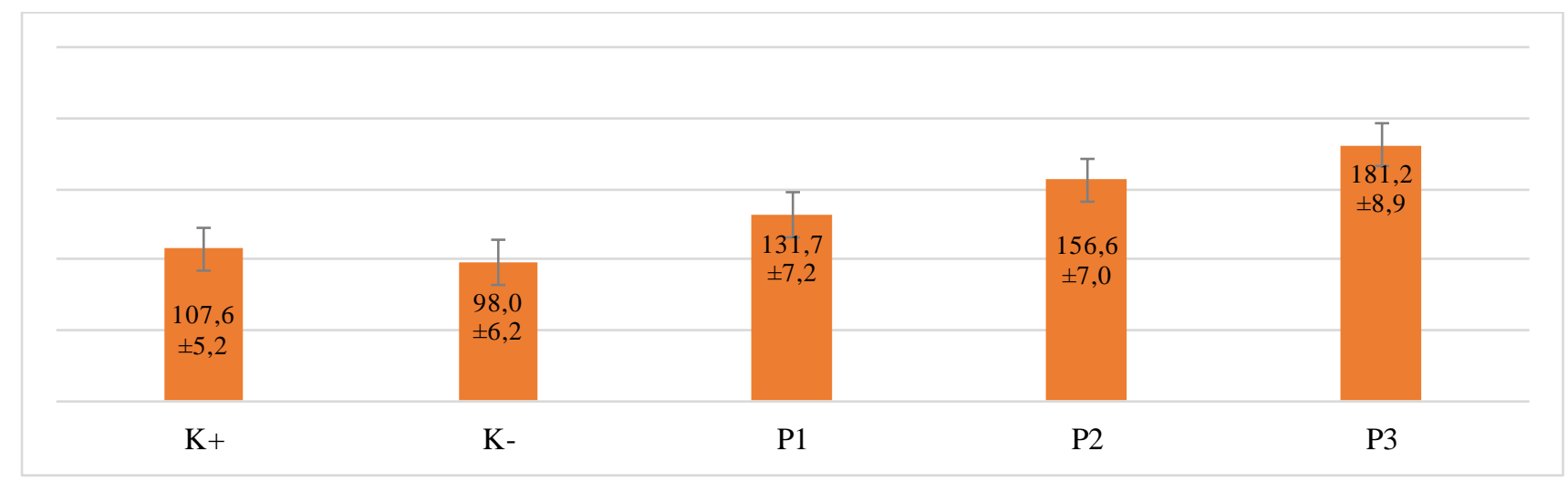

Figure 2 Number of Spermatid Cells

*Note: $(\mathrm{K}+)$ Normal Group. (K-) mice were given a 12-hours noise stressor treatment. $(\mathrm{P} 1)$ mice were treated with 12 hours noise stressors and 1-hour Murottal Al-Qur'an therapy. (P2) mice were given a 12-hours noise stressor treatment and 2-hours Murottal Al-Qur'an therapy. (P3) mice were given a 12-hour noise stressor treatment and 4-hour hours Murottal Al-Qur'an therapy.

\section{Discussion}

Based on research on the effect of Murottal Al-Qur'an therapy on spermatogenesis of male mice with stress cause noise stressors shows the Murottal AlQur'an therapy can reduce stress cause noise stressors. This result is proven from the observation of the number of primary spermatocytes and spermatids in the testicular histology preparations of mice that have increased compared to the group of mice with stress.

Stress will disrupt the body's homeostatic system, which results in physical and psychological symptoms. ${ }^{2}$ One of the stressors that trigger stress is noise. Noise is a stressor that can stimulate the sympathetic nervous system and the activity of the adrenal hypothalamic-pituitary (HPA). The HPA will accept noise stressor and stimulate to secrete corticotropinreleasing hormone $(\mathrm{CRH})$. The anterior pituitary then stimulates to synthesize the hormone adrenocorticotropin (ACTH). $\mathrm{ACTH}$ will trigger the adrenal cortex to secrete glucocorticoid hormones, namely cortisol. $^{13}$ Cortisol is one of the main hormones that play a role in the stress response. $^{14}$

When the body is exposed to stressors, cortisol will inhibit the process of spermatogenesis. Cortisol inhibits the secretion of gonadotropin releasing- hormone $(\mathrm{GnRH})$ and suppresses release of luteinizing hormone (LH) and Folliclestimulating hormone (FSH). Decrease of cortisol also suppresses the production of gonadotropin releasing-hormone $(\mathrm{GnRH})$ and suppresses the release of luteinizing hormone (LH) and Follicle-stimulatinghormone $(\mathrm{FSH})$. Testosterone by Leydig cells, spermatozoa by Sertoli cells, and disrupt the process of spermatogenesis. ${ }^{6}$ The disruption of the spermatogenesis process could be seen histologically from the number of spermatogenic cells making up the seminiferous tubules that are reduced. ${ }^{15}$

Based on research, there was a decrease in primary spermatocytes and spermatids in the negative group with noise; this is due to a decrease in reproductive hormones that are inhibited by the hormone cortisol. Besides spermatocyte cells, which are very sensitive to external influences and will tend to suffer damage after the first meiosis, primary spermatocyte cells that are damaged will be phagocytosed by Sertoli that can decrease the number of primary spermatocyte cells. Decreased primary spermatocyte cells will decrease spermatid cells as well because there will be fewer primary spermatocyte cells that will undergo division into spermatid cells. ${ }^{16}$

Murottal that is played to humans can affect both the body, where sounds that contain harmonious and regular tones can 
produce rhythmic stimulation to the central nervous system so that the body becomes stable. This happens because the brain's performance that controls and coordinates all body activities becomes homeostasis. ${ }^{17}$

Murottal Al-Qur'an can be used as a new alternative therapy as a relaxation therapy even better than other audio therapies because the stimulant Al-Qur'an can cause delta waves of $63.11 \%$. This audio therapy is also cheap and does not cause side effects. ${ }^{9}$ Delta waves are brain waves that have large amplitude and low frequency, which is below $4 \mathrm{~Hz}$. This wave arises when someone falls asleep without dreaming, so the delta wave is also called the resting phase because, during sleep, the body will perform a self-healing process, repair damaged tissue, and produce new cells. ${ }^{18}$ In addition to delta waves, when listening to Murottal Al-Qur'an, the brain will generate alpha waves, Alpha waves are brain waves that occur when a person experiences relaxation. $^{19}$

When listening to the Murottal of the Qur'an, the body will be in a state of relaxation that triggers the release of beta- endorphin. ${ }^{20}$ Beta-endorphin modulates the occurrence of steroidogenesis in mice. ${ }^{21}$ Steroidogenesis itself is a process of the formation of steroid hormones both in the adrenal glands, testes, and ovaries. The steroidogenesis triggers Leydig cells to produce the hormone testosterone. It was significant to the process of spermatogenesis. $^{22}$

The duration of Murottal Al-Qur'an exposure affects the spermatogenesis process. It is seen from the number of primary spermatocytes and spermatids. The study found that the number of cells in the 4-hour treatment group showed a higher increase in the number of cells compared to other treatment groups; this proves that the longer the administration of Murottal, the better the therapeutic effect is caused. It is a picture of spermatogenic cells in the seminiferous tubules of each treatment.

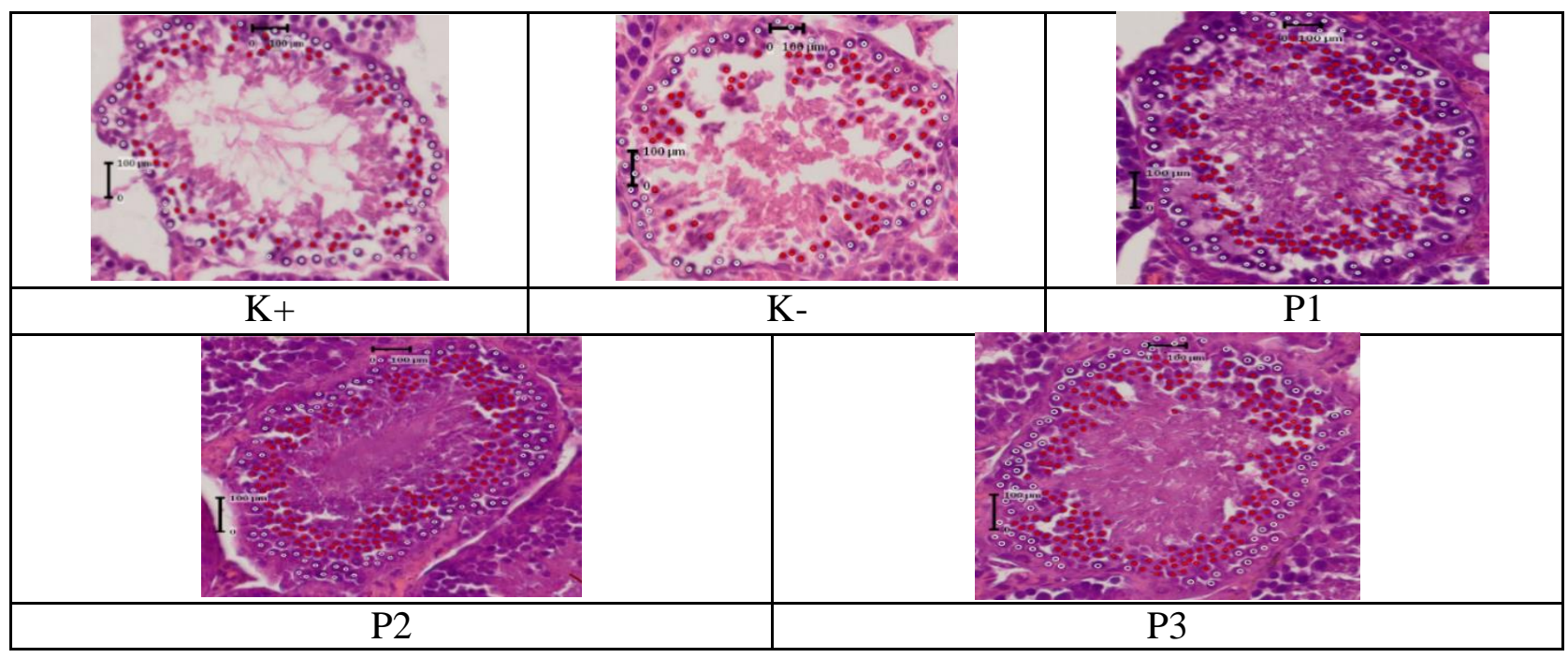

Figure 3 Testicular Histology of Control and Treatment Group at 40x Magnification.

*Note: $(\mathrm{K}+)$ mice were not treated. $(\mathrm{K}-)$ mice were given a 12-hour noise stressor treatment. $(\mathrm{P} 1)$ mice were treated with 12-hour noise stressors and 1-hour Murottal Al-Qur'an therapy. (P2) mice were given a 12-hour noise stressor treatment and 2-hour Murottal Al-Qur' an therapy. (P3) mice were given a 12-hour noise stressor treatment and 4-hour Murottal AlQur'an therapy. (White dot) primary spermatocy tes. (Red dot) spermatid. 


\section{CONCLUSION}

Murottal

Al-Qur'an,

as

nonpharmacological therapy with several variations duration, affects the spermatogenesis of mice. It is seen from the significant increase in the number of primary spermatocytes and spermatid cells p> 0.05. Murottal, 4-hour therapy, provides the best therapeutic effect when compared with other therapies. And we suggestion for future researchers to conduct research on other fertility parameters.

\section{REFERENCE}

1. Halter, M.J. 2014. Varcarolis' foundations of psychiatric mental health nursing: A clinical approach (7th ed.). Missouri: Elsevier.

2. Huda, M.M dan Prastyowati, Intan. 2016. Stres Masyarakat Terjadi Akibat Intensitas Suara Bising Mesin Diesel Penggilingan Pakan Ternak Sapi: Studi Masyarakat Pandantoyo Kediri. NurseLine Journal. 1 (1). P. 18-23.

3. Riskesdas. 2013. Laporan Hasil Riset Kesehatan Dasar (Riskesdas) 2013. Jakarta : Kementrian Kesehatan RI

4. World Health Organization. 2016. Global Health Observatory Data. Diakses pada tanggal 01 Juni 2019

5. Ranabir, S., dan Reetu, K. 2011. Stress and hormones. Indian Journal of Endocrinology and Metabolism. 15(1). P.18-22.

6. Arjadi, Fitranto. 2016. Pengaruh Berbagai Model Stres Terhadap Fungsi Reproduksi Tikus Putih Jantan (Rattus Norvegicus) [Disertasi]. Yogyakarta: UGM.

7. Apriliani, Mustika., Nurcahyani, Nuning., Busman, Hendri. 2013. Efek Pemaparan kebisingan terhadap jumlah sel spermatogenik dan diameter tubulus seminiferous mencit (Mus musculus). Seminar Nasional Sains dan Teknology. Lampung : Universitas Lampung
8. Rojas, lizbeth J., Villasenor. R.M., Casillas, F. 2017. Gradual Decrease in Spermatogenesis Caused by Cronic Stress. Asta histochemica. 119. P. 284291

9. Abdurrahman, A., Perdana, S., Andika, S. 2008. Murottal Al-Qur'an: Alternatif Terapi Suara Baru. Proseding Seminar Nasional Sains dan Teknologi. Lampung: Universitas Lampung

10. Gunawan, 2009. Hypnosis the Art of Subsconcius Communication. Jakarta: Gramedia.

11. Susianti PR., Kurniawati., E. 2012. Pengaruh Pemberian Ektrak Etanol Jahe Putih (Zingiber Officinale Roscoe) terhadap Gambaran Histologi Testis Mencit (Mus musculus L) Jantan Galur Ddy Yang Diinduksi Etanol. Jurnal Kedokteran dan Kesehatan. 2(2):P 511.

12. Sarojo, GA. 2011. Gelombang dan Optika. Jakarta:Salemba Teknika.

13. Taban, E., S. B. Mortazav, S., Vosoughi, A., Khavanin, dan H.A. Mahabadi. 2017. Noise Exposure Effect on Blood Glucose, Cortisol And Weight Changes In The Male Mice. Health Scope. 6(2).

14. Guilliams, T dan Edwards, L, 2010. Chronic Stress and the HPA Axis: Clinical Assessment and Therapeutic Considerations'.The Standard. 9(2).P. 1-12

15. Arief, Yuni. 2011. Stres Dapat Mengganggu Proses Spermatogenesis Pada Mencit. Jurnal Ners.6(2).P.169174.

16. Everitt, B. 1990. Essential in Reproduction, London: Blackwell Science Pub Oxford.

17. Riyacumala V., Mohammad K., Prasetyanigtyas WE., Nurhidayat. 2012. Pertumbuhan dan Sekresi Protein Hasil Kultur Primer Sel-Sel Serebrum Anak Tikus. J Veteriner. 13(2): P. 125-135.

18. Mustajab. 2010. Rahasia Dahsyat Terapi Otak. Jakarta: PT. Wahyu Media. 
19. Dryden, G. 2000. Revolusi Cara Belajar. Bandung: Kaifa.

20. Rizka, Zakiyyatun. 2015. Pengaruh Pemberian Murottal Al-Qur'an terhadap Tekanan Darah dan Frekuensi Denyut Jantung Pasien Pasca Operasi dengan Anestesi Umum di Rumah Sakit Umum Daerah Dr. Moewardi Surakarta. Naskah Publikasi. Surakarta: UMS. P.5.

21. Chandrashekar, Vadaran., Bartke, Andrzej. 1992. The Influence of Beta-
Endorphin on Testicular Endocrine Function in Adult Rats. Biology of Reproduction. 47(1).P.1-5

22. Cholifah, Siti., Arsyad., Salni. 2014. Pengaruh Pemberian Ekstrak Pare (Momordic charantia) terhadap Stuktur Histologi Testis dan Epidedemis Tikus Jantan (Rattus norvegius). MKS. 46(2).P.149-157 